\title{
Haemorrhagic smallpox
}

\author{
By A. W. DOWNIE, D. S. FEDSON, L. St VINCENT, A. R. RAO \\ AND C. H. KEMPE \\ Department of Pediatrics, University of Colorado Medical Center, \\ and the Infectious Disease Hospital, Tondiarpet, Madras
}

(Received 12 April 1969)

The most acutely fatal cases of smallpox in which death occurs within 8 days of the onset of illness, often before focal lesions are present in the skin, have been classified by Dixon (1962) as fulminating. The majority of these patients show petechial haemorrhages in the skin, bleeding into the conjunctiva and from the mouth, nose, rectum, vagina and often frank blood in the urine. These cases have been classified by Rao as haemorrhagic type I (Ramsay \& Emond, 1967). A second severe type of infection is manifested by the appearance of a flat, often delayed, focal eruption in the skin associated with haemorrhages at the base of vesicles, but also into apparently normal skin between focal lesions. The majority of these patients die from 8 to 12 days after onset and have been classified by Rao as haemorrhagic type II.

It has been suggested that these severe infections associated with haemorrhage are manifestations of an allergic reaction (Dixon, 1962; Herrlich, Mayr \& Mahnel, 1959); approximately $50 \%$ have a history of previous vaccination. Defects in the clotting mechanism have been revealed by the studies of Roberts et al. (1965) and McKenzie et al. (1965). The severity of the virus infection in these patients has been shown by the severe and sometimes prolonged viraemia determined by blood culture (Downie et al. 1953; Mitra et al. 1966) and by the presence of soluble antigen in the blood of a proportion of them. This antigen has been detectable by complement-fixation tests (Downie et al. 1953) or in a few instances by precipitation in agar gel (Paniker \& Kalra, 1962).

The present studies were carried out on a series of haemorrhagic smallpox patients seen in the Infectious Disease Hospital in Madras between the years 1963 and 1966. They were designed to determine the presence of virus and virus antigen in the blood and the immune response in these patients as measured by antibody estimations on blood serum. Examination of blood for virus was made immediately after its collection, while tests for the presence of soluble antigen were made in Madras and later repeated in Denver on samples of serum or plasma which had been kept frozen at -20 to $-30^{\circ} \mathrm{C}$. until 1967. The determinations of antibody by precipitation in agar gel were made in Madras and later repeated in Denver.

Requests for reprints should be addressed to Dr C. H. Kempe, 4200 East Ninth Avenue, Denver, Colorado 80220. 


\section{MATERIAL AND METHODS}

There were 77 patients included in the study. Of these 37 were classified as type I on clinical grounds by one of us (A. R.) and 40 as type II. There were 39 females and 38 males. Five of the type II patients survived. Of the females 13 were known to be pregnant and 10 of these suffered from type I disease. Of the 77 patients, 20 bore no scars of vaccination. Only three of the patients were under the age of 10 years. Tests for antibody in the serum by three or four techniques were carried out in 47 cases.

\section{Detection and measurement of viraemia}

This examination was carried out on $\mathbf{7 5}$ of the cases and in one patient on three separate occasions. Blood was collected in most cases into heparin. In 42 instances the blood was centrifuged, the plasma removed, the buffy coat pipetted off and washed once before suspension in a volume of diluent equal to the original blood sample. The leukocytes, whole blood and plasma were tested separately by inoculation of $0.1 \mathrm{ml}$. quantities on the chorioallantois (CA) of two or three 12-day chick embryos. The eggs were examined 3 days later and the number of lesions noted. Where there was doubt about occasional lesions, the excised chorioallantois was extracted and inoculated into further eggs. There was little difference in the results obtained from the plasma and washed buffy coat, but in three specimens, whole blood and leucocytes yielded a few lesions on the chorioallantois when the plasma was negative. Twelve specimens were tested by inoculation into tissue cultures of Hela cells as well as on chick embryos. On only one of these specimens, which was positive on the CA and negative on tissue culture, did the results differ. In the subsequent figures and tables the degree of viraemia has been recorded in plus signs: + represents $1-10$ lesions on the $\mathrm{CA} ;++, 10-100$ lesions;,+++ 100 1000 lesions or semiconfluent takes; and ++++ , confluent takes on the CA.

\section{Detection of antigen in the blood serum or plasma}

The sera from many of the cases were tested in Madras for antigen by the precipitation-in-agar-gel technique. The sera were tested undiluted against a vaccinia immune rabbit serum or against a convalescent smallpox serum which gave strong reactions with antigen from smallpox vesicle fluid or from vaciniainfected rabbit skin. The sera were tested for antigen by the complement-fixation technique only in Denver in 1967. Between the tests for antigen in Madras and the tests in Denver the sera had been stored frozen but had been heated three times at $58^{\circ} \mathrm{C}$. to render them non-infectious before being shipped from Madras to Liverpool and again from Liverpool to Denver. This heating affected the results of precipitation tests for antigen; for 16 sera showed antigen by precipitation in Madras, and only two gave positive reactions for antigen by precipitation in Denver. On the other hand, all sera which showed antigen by precipitation in Madras showed good titres for antigen when tested by complement fixation in Denver. Dumbell \& Nizamuddin (1959) remarked that heating at $60^{\circ} \mathrm{C}$. greatly lessened the activity of crust extracts when tested for antigen by precipitation in agar gel. 
Because of the apparent discrepancy between the result of precipitation tests for antigen in Madras and in Denver, experiments were made by adding rabbit vaccinial antigen to a normal human serum and testing the mixture for antigen by both precipitation and complement-fixation tests before and after heating for 15 and for $30 \mathrm{~min}$. at $59^{\circ} \mathrm{C}$. The unheated antigen gave positive precipitation reactions up to dilutions of $1 / 16$, whereas the heated antigen gave weak positive reactions only at a dilution of $1 / 2$. On the other hand, the heated antigens had undiminished complement-fixing activity (Table 1). It would appear, therefore,

Table 1. Complement-fixing activity of antigen-in-serum, heated for 15 and 30 min. at $59^{\circ} \mathrm{C}$.

\begin{tabular}{|c|c|c|c|c|c|c|c|c|}
\hline \multirow{2}{*}{$\begin{array}{l}\text { Antigen in } \\
\text { serum }\end{array}$} & \multicolumn{7}{|c|}{ Antigen dilutions } & \multirow{2}{*}{$\begin{array}{c}\text { Antigen } \\
\text { controls } \\
1 / 100\end{array}$} \\
\hline & $1 / 100$ & $1 / 200$ & $1 / 400$ & $1 / 800$ & $1 / 1600$ & $1 / 3200$ & $1 / 6400$ & \\
\hline $\begin{array}{l}\text { Heated } 15 \text { min., } \\
59^{\circ} \mathrm{C} .\end{array}$ & ++++ & ++++ & ++++ & +++ & ++++ & +++ & - & - \\
\hline $\begin{array}{l}\text { Heated } 30 \text { min., } \\
59^{\circ} \mathrm{C} .\end{array}$ & +++ & ++++ & ++++ & +++ & +++ & ++ & - & - \\
\hline $\begin{array}{l}\text { Unheated } \\
\text { Antiserum }\end{array}$ & & ++++ & +++ & +++ & +++ & ++++ & - & - \\
\hline control, $1 / 80$ & - & . & . & . & & . & . & \\
\hline
\end{tabular}

that the combination of heated antigen plus antibody may fail to precipitate in agar gel, but complement-fixing activity is unimpaired. It may be noted that heating of sera to $59^{\circ} \mathrm{C}$. has no deleterious effect on precipitating or CF antibody. In the results shown below those of precipitation tests for antigen were obtained in Madras, while the results of tests for antigen by complement fixation are those obtained in Denver. In these CF tests sera were tested for antigen in dilutions from 1/10 upwards against an antivaccinial rabbit serum used at optional dilution $(1 / 80)$.

\section{Tests for antibody}

The techniques used for antibody estimations were those described in the previous paper (Downie, St Vincent, Rao \& Kempe, 1969).

\section{RESULTS}

The severity of infection as reflected by the presence of virus or virus antigen in blood

The findings in relation to the degree of viraemia on different days after onset are shown in Fig. 1. The type I cases showed the heavy viraemia in the early days of illness, but in a few of the type II cases the viraemia was still pronounced before death. Of the unvaccinated patients, four, examined on the 7th, 8th, 9th and 11th days, showed no viraemia by the techniques used and of the remaining 16 shown in Fig. 1 , nine had a ++++ viraemia. Of the five type II patients who survived three had + viraemia on the 5th, 6 th and 7 th days and two were negative 
on the 7th and 9th days. Only after the 8th day of illness (type II cases) were there more negative than positive blood cultures (5 to 4).

Of the 16 patients who showed antigen in serum by the precipitation-in-agar-gel test all had viraemia of ++++ degree (Table 2); all were type I cases. One was

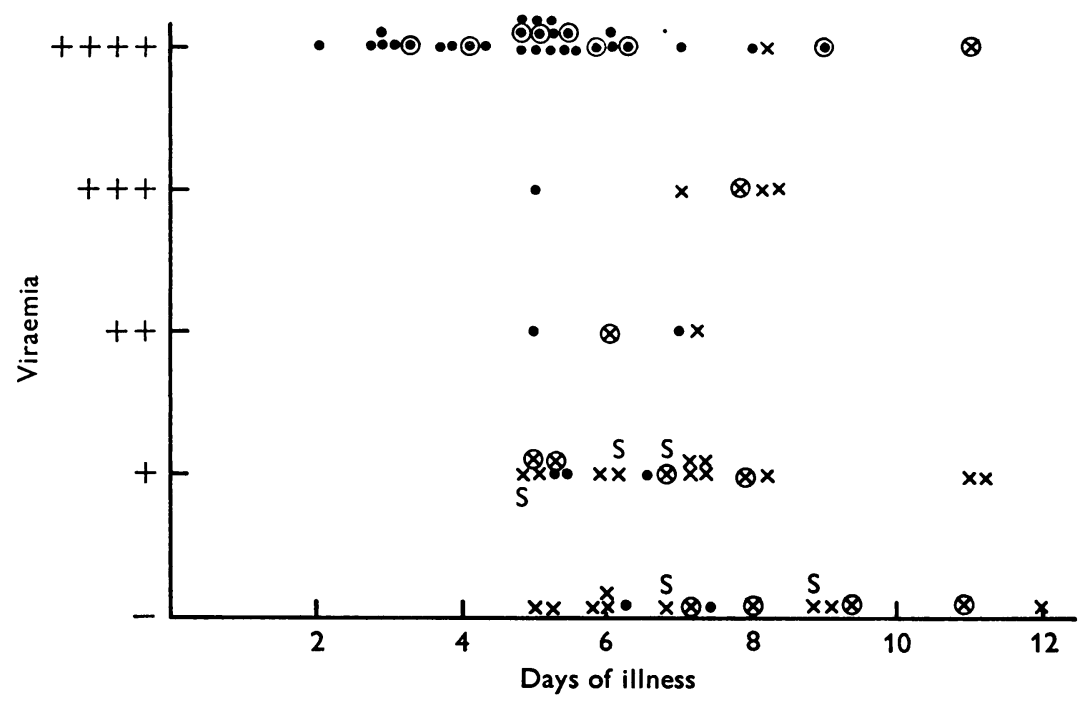

Fig. 1. Viraemia in haemorrhagic smallpox patients. $\bullet$, Type I; $\times$, type II; $\odot, \otimes$, unvaccinated, type I or type II; S, survived.

Table 2. Relationship of viraemia to antigen in blood serum detected by precipitation in agar gel

$\begin{array}{crr}\text { Blood culture } & \overbrace{-}^{\text {Precipitinogen }} \\ - & - & + \\ + & 9 & 0 \\ ++ & 11 & 0 \\ +++ & 2 & 0 \\ ++++ & 2 & 0 \\ \text { Totals } & 4 & 16 \\ & 28 & 16\end{array}$

Table 3. Comparison of results of tests for antigen in serum by precipitation in agar gel and by complement fixation

Complement-fixation
titre
$<10$
10
20
40
80
160

Totals

\begin{tabular}{|c|c|}
\hline \multicolumn{2}{|c|}{ Precipitinogen } \\
\hline- & + \\
\hline 0 & 0 \\
\hline 3 & $\mathbf{0}$ \\
\hline 6 & 2 \\
\hline 4 & \\
\hline 0 & $\mathbf{5}$ \\
\hline 0 & $\mathbf{3}$ \\
\hline 23 & 15 \\
\hline
\end{tabular}


positive on the 7th day, the others on the 2nd to 6th day of illness. The results of tests for antigen in the blood by complement fixation are shown in Fig. 2. The high titres of antigen were shown in specimens examined up to the 6th day of illness. Of the 38 sera examined for antigen both by precipitation and CF techniques, 15 were positive by precipitation and 28 by CF (Table 3 ). All eight sera giving a titre of $1 / 80$ or $1 / 160$ by CF, five of nine giving a titre of $1 / 40$ and two of eight giving a titre of $1 / 20$ were positive by the precipitation tests. The CF technique

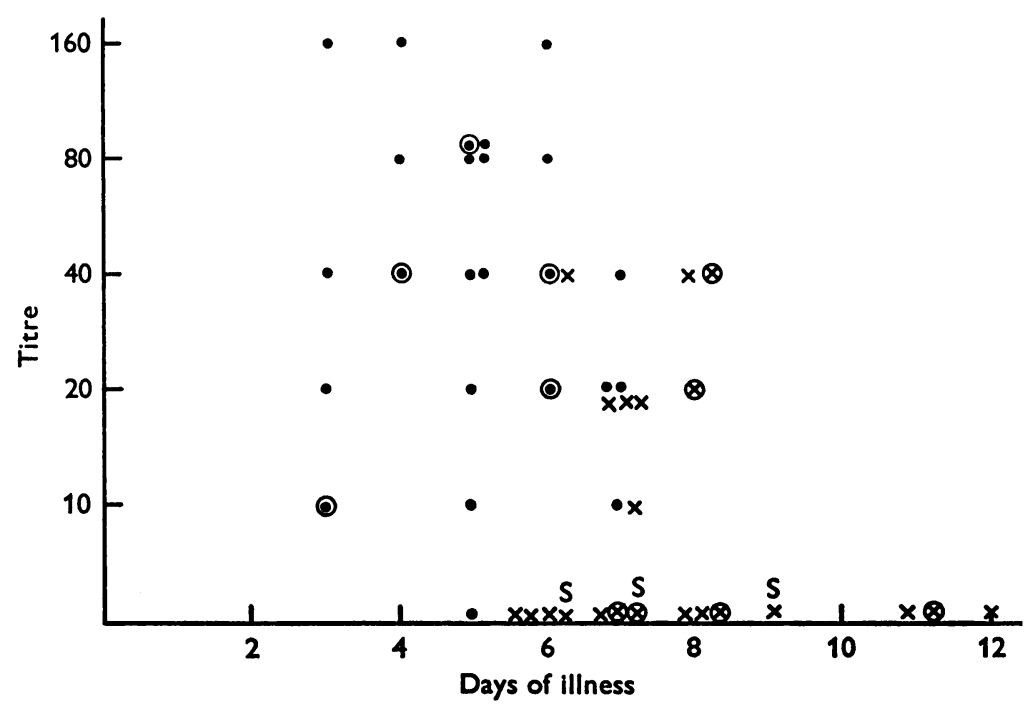

Fig. 2. Antigen in serum of haemorrhagic smallpox patients. $\bullet$, Type I; $\times$, type II; $\odot, \otimes$, unvaccinated, type I or type II; S, survived.

Table 4. Relationship of viraemia to presence of antigen in serum measured by complement-fixation technique

\begin{tabular}{crrrrrrr} 
Blood & \multicolumn{7}{c}{ CF antigen titre } \\
culture & $<10$ & 10 & 20 & 40 & 80 & 160 & Totals \\
- & 7 & 1 & - & - & 1 & - & 9 \\
+ & 4 & 2 & 3 & 1 & - & - & 10 \\
++ & - & 1 & 2 & - & - & - & 3 \\
+++ & 2 & - & - & 2 & - & - & 4 \\
++++ & - & 1 & 3 & 6 & 5 & 3 & 18 \\
Totals & 13 & 5 & 8 & 9 & 6 & 3 & 44
\end{tabular}

is obviously a more sensitive test for detecting antigen in blood than is the precipitation-in-agar-gel test. In general, the amount of antigen detected in the blood (CF technique) was proportional to the degree of viraemia (Table 4), although there were two patients with +++ viraemia in whom antigen was not detected. One patient, who had an antigen titre in his blood of $1 / 80$ by CF test, had no virus in his serum, but whole blood was not cultured from this patient. 
These findings are set out in relation to the two types of haemorrhagic smallpox in Table 5. The results in the two type II cases showing a ++++ viraemia were obtained on the 8th and 11th days of illness, the day of death in each case. It can be seen from Table 5 that the greater severity of infection in type I patients is reflected in the greater degree of viraemia and amount of soluble antigen in the blood. Examinations were made earlier in type I patients as they did not live so long, but the difference is apparent if those examined on the 6th and 7th days are compared (see Figs. 1 and 2, and Table 6).

Table 5. Virus and virus antigen in blood of types I and II haemorrhagic smallpox patients

$\begin{array}{lccccccccc}\text { Degree of viraemia } & & \overbrace{+}^{\text {Precipitation }} & - & + & \text { Complement fixation } \\ \text { Type I } & 30 & 0 & 2 & 3 & 2 & 16 & 6 & 23 & - \\ \text { Type II } & 2 & 4 & 3 & 14 & 13 & 0 & 23 & 9 & 1\end{array}$

\section{Antibody studies in haemorrhagic smallpox}

These were carried out in only 47 patients and the results are shown in Table 6. The results from type I and type II patients are listed separately in order of the days of illness on which specimens were collected.

\section{Precipitins}

Only five gave a precipitation test in agar gel for antibody when tested with a vaccinial or smallpox antigen (nos. 26, 31, 42, 43 and 46). All were type II cases. In four of the five, antibody was detectable by CF test and all five had a neutralizing titre of 1 in 90, or over. Virus was present in small amount in the blood of two (nos. 31 and 42, Table 6).

\section{Haemagglutinin inhibiting antibody}

The results of these tests are shown in Fig. 3 and Table 6. The results in unvaccinated patients tended to be lower than the others. But the titre of $\mathrm{HI}$ antibodies were not appreciably less than those in non-haemorrhagic cases (compare Fig. 3, and fig. 2 in the previous paper (Downie, St Vincent, Goldstein, Rao \& Kempe, 1969)).

\section{CF antibody}

Only six patients showed antibody in serum by this test. All were type II cases and all had neutralizing titres of $1 / 68$ or over. In one of these patients (no. 31, Table 6) both antigen and antibody were detected in the blood by the CF technique. 
Table 6. Virus, antigen and antibody in blood of types I and II haemorrhagic smallpox patients

\begin{tabular}{|c|c|c|c|c|c|c|c|c|c|c|c|}
\hline \multirow{2}{*}{$\begin{array}{l}\text { Case } \\
\text { no. }\end{array}$} & \multirow{2}{*}{$\begin{array}{l}\text { Age } \\
\text { and } \\
\text { sex }\end{array}$} & \multirow{2}{*}{$\begin{array}{c}\text { Vaccination } \\
\text { history }\end{array}$} & \multirow[b]{2}{*}{$\begin{array}{l}\text { Day of } \\
\text { collection }\end{array}$} & \multirow{2}{*}{$\begin{array}{l}\text { Virus in } \\
\text { blood }\end{array}$} & \multicolumn{2}{|c|}{$\begin{array}{l}\text { Antigens } \\
\text { in blood }\end{array}$} & \multicolumn{4}{|c|}{ Antibody in serum } & \multirow{2}{*}{$\begin{array}{l}\text { Day } \\
\text { of } \\
\text { death }\end{array}$} \\
\hline & & & & & Ppt. & $\mathrm{CF}$ & Ppt. & CF & HI & Neut. & \\
\hline \multicolumn{12}{|c|}{ Haemorrhagic smallpox type 1} \\
\hline 1 & $40 \mathrm{~F}$ & + & 3 & ++++ & + & 160 & - & - & 10 & $<10$ & 3 \\
\hline 2 & $30 \mathrm{~F}$ & + & 3 & ++++ & + & 40 & - & - & 160 & $<20$ & 4 \\
\hline 3 & $20 \mathrm{FP}^{*}$ & - & 3 & +++ & - & 10 & - & - & $<10$ & 12 & 4 \\
\hline 4 & $36 \mathrm{~F}$ & + & 3 & +++ & + & 20 & - & - & 20 & $<\mathbf{3 0}$ & 4 \\
\hline 5 & 22 FP & + & 4 & ++++ & + & 80 & - & - & 20 & $<10$ & 4 \\
\hline 6 & $25 \mathrm{~F}$ & - & 4 & +++ & + & 40 & - & - & NT & $<10$ & 4 \\
\hline 7 & $22 \mathrm{~F}$ & + & 4 & +++ & + & 160 & - & - & 20 & 35 & 4 \\
\hline 8 & $26 \mathrm{M}$ & + & 5 & ++++ & + & 80 & - & - & NT & $<10$ & 5 \\
\hline 9 & $30 \mathrm{FP}$ & + & 5 & +++ & + & 40 & - & - & 40 & $<20$ & 5 \\
\hline 10 & $25 \mathrm{~F}$ & + & 5 & +++ & NT & - & - & - & 20 & 10 & 5 \\
\hline 11 & $22 \mathrm{M}$ & + & 5 & ++++ & + & 20 & - & - & 80 & 40 & 6 \\
\hline 12 & $18 \mathrm{FP}$ & + & 5 & ++++ & + & 80 & - & - & 40 & $<10$ & 6 \\
\hline 13 & $7 \mathrm{M}$ & + & 5 & +++ & + & 80 & - & - & 20 & $<20$ & 6 \\
\hline 14 & $25 \mathrm{FP}$ & + & 5 & + & NT & 10 & - & - & NT & 30 & 6 \\
\hline 15 & $14 \mathrm{~F}$ & + & 5 & ++++ & - & 40 & - & - & 40 & $<10$ & 7 \\
\hline 16 & $28 \mathrm{~F}$ & - & 5 & ++++ & + & 80 & - & - & 20 & $<10$ & 11 \\
\hline 17 & $30 \mathrm{FP}$ & + & 6 & ++++ & + & 160 & - & - & 40 & $<20$ & 6 \\
\hline 18 & $24 \mathrm{M}$ & - & 6 & ++++ & + & 40 & - & - & 40 & $<10$ & 6 \\
\hline 19 & $30 \mathrm{FP}$ & + & 6 & $-\dagger$ & NT & 80 & - & - & 40 & $<10$ & 7 \\
\hline 20 & $55 \mathrm{M}$ & - & 6 & ++++ & - & 20 & - & - & 10 & $<10$ & 8 \\
\hline 21 & $28 \mathrm{FP}$ & + & 7 & ++ & - & 20 & - & - & 80 & 125 & 7 \\
\hline 22 & $29 \mathrm{~F}$ & + & 7 & - & - & 10 & - & - & 80 & 20 & 7 \\
\hline 23 & $25 \mathrm{M}$ & + & 7 & ++++ & + & 40 & - & - & 40 & $<10$ & 8 \\
\hline 24 & $30 \mathrm{M}$ & + & 7 & + & - & 20 & - & - & 40 & 47 & 8 \\
\hline
\end{tabular}

$\begin{array}{lll}25 & 37 \mathrm{FP} & \\ 26 & 50 \mathrm{~F} & + \\ 27 & 53 \mathrm{M} & + \\ 28 & 25 \mathrm{M} & + \\ 29 & 25 \mathrm{~F} & + \\ 30 & 30 \mathrm{M} & + \\ 31 & 30 \mathrm{~F} & + \\ 32 & 26 \mathrm{FP} & + \\ 33 & 28 \mathrm{M} & + \\ 34 & 22 \mathrm{M} & + \\ 35 & 17 \mathrm{M} & - \\ 36 & 20 \mathrm{M} & - \\ 37 & 25 \mathrm{~F} & - \\ 38 & 23 \mathrm{M} & + \\ 39 & 20 \mathrm{~F} & - \\ 40 & 35 \mathrm{FP} & + \\ 41 & 25 \mathrm{M} & - \\ 42 & 41 \mathrm{M} & + \\ 43 & 32 \mathrm{~F} & + \\ 44 & 55 \mathrm{~F} & - \\ 45 & 70 \mathrm{M} & + \\ 46 & 25 \mathrm{~F} & + \\ 47 & 30 \mathrm{M} & ?\end{array}$

Haemorrhagic smallpox type II

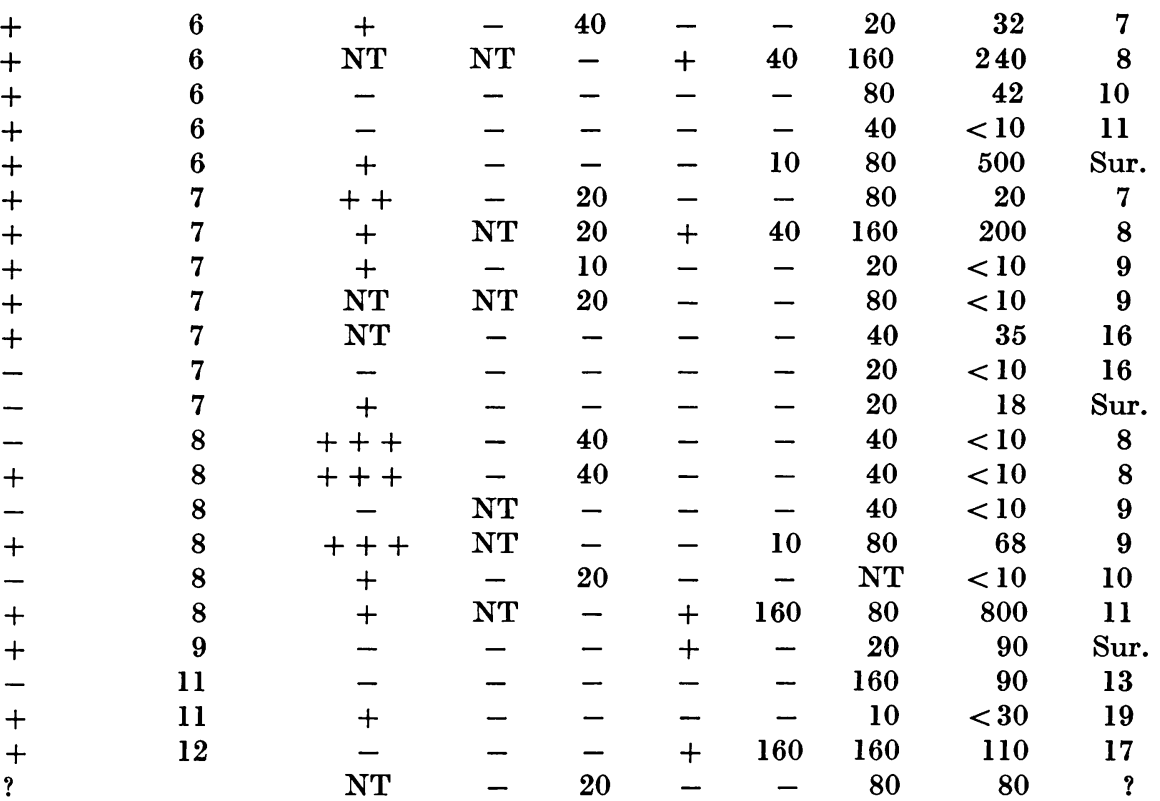

Ppt. = precipitation test $; \mathrm{CF}=$ complement-fixation test; $\mathrm{HI}=$ haemagglutinin inhibition test; neut. = neutralization test; $\mathrm{NT}=$ not tested; Sur $=$ survived.

* $\mathrm{P}$ after $\mathrm{F}=$ pregnant.

$\dagger$ Only blood serum tested for virus. 


\section{Neutralizing antibody}

The titres of neutralizing antibody are shown in Fig. 4 and Table 6. They are obviously low in comparison with those found for non-haemorrhagic cases (fig. 4 of the previous paper).

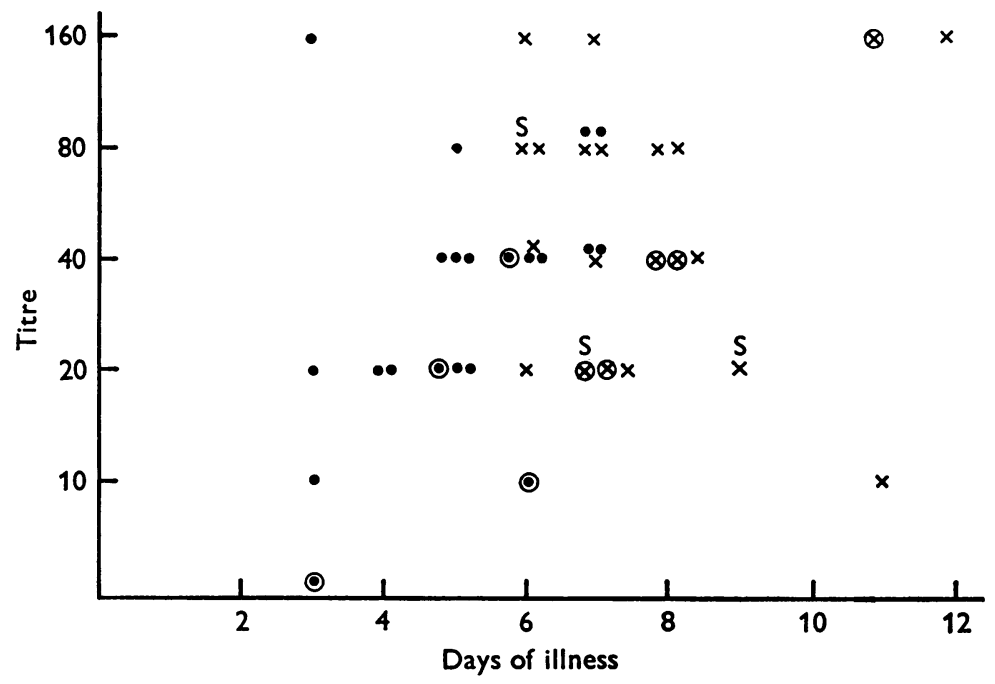

Fig. 3. Haemagglutinin-inhibiting antibody in serum of haemorrhagic smallpox patients. $\bullet$, Type I; $\times$, type II; $\odot, \otimes$, unvaccinated, type I or type II ; S, survived.

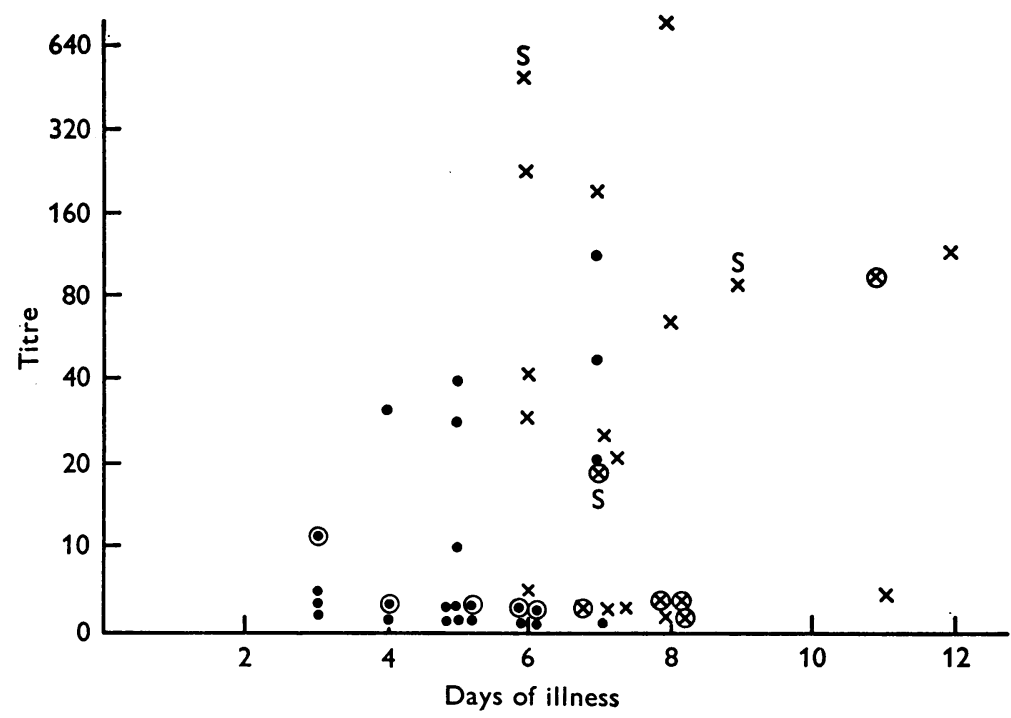

Fig. 4. Neutralizing antibody in serum of haemorrhagic smallpox patients. •, Type I; $x$, type II; $\odot, \otimes$, unvaccinated, type I or type II; S, survived.

In general, the type II patients showed higher antibody titres than the type I patients. This appears to be so when the comparison is restricted to results on sera collected on the 6th and 7th days of illness. The five patients who recovered were type II infections. 


\section{DISCUSSION}

The haemorrhagic cases of smallpox differ from the other clinical types in that virus is found in the blood of the haemorrhagic cases in greater amounts and later in the disease (Downie et al. 1953; Mitra et al. 1966). This has been confirmed in the present study, although examination for virus was made in a comparatively small number of the non-haemorrhagic patients. Virus was found in small amounts between the 4th and 7th days of illness in the blood of two nonhaemorrhagic cases and three type II haemorrhagic cases who recovered. The finding of small amounts of virus in the blood after the second day of illness does not necessarily indicate a fatal illness as suggested by Downie et al. (1953). In none of the nonhaemorrhagic cases of smallpox was soluble antigen found in blood whereas it was present in most of the type I and in more than a third of the type II haemorrhagic patients. These findings show that particularly in type I haemorrhagic smallpox there is an overwhelming proliferation of virus in the tissues with overflow of virus into the circulation and the appearance there of soluble viral antigens often in high concentration. The situation is perhaps similar to that in acute meningococcal septicaemia which may present a similar clinical picture. Many of the patients die before an antibody response might be expected in an ordinary case, but in those who survive beyond the sixth day of illness, antibody response is poor or absent (Table 6).

The haemorrhages into the skin and mucous membranes which are a feature of the most severe forms of smallpox probably result from the severity of the generalized infection. Histological evidence indicates that before skin lesions appear there is infection of capillaries in the dermis as indicated by swelling of the vascular endothelium and an infiltrate of mononuclear cells around the vessels. Indeed growth of virus in the endothelial lining of these vessels may contribute to the prolongation of viraemia in severe cases. The damage to the walls of capillaries may be severe enough to permit the extravasation of blood and may trigger disseminated intravascular clotting as in other viral diseases characterized by haemorrhages into the skin (McKay \& Margaretten, 1967). It has been suggested that the defects in the clotting mechanism found in haemorrhagic smallpox are a consequence of disseminated intravascular clotting (Roberts et al. 1965; McKenzie et al. 1965). These defects may contribute to the bleeding tendency and be amenable to therapy with heparin to interrupt the intravascular clotting.

Herrlich et al. (1959),* because of the early appearance of antibody in eight of ten cases of primary haemorrhagic smallpox and the occurrence of this form of the disease in vaccinated persons, suggested that allergy might play a part in its causation. The antibodies were demonstrated mostly by HI tests and estimation of neutralizing antibody titres was not made. Our own experience recorded above and that of Sarkar, Chatterjee \& Mitra (1967) indicates that the overall antibody response is poor in haemorrhagic cases. It is true that haemorrhagic infections are seen frequently in patients who show scars from previous vaccination, but the

* Herrlich no longer believes that allergy is an important factor in the genesis of haemorrhagic smallpox (personal communication). 
extensive data from Madras indicate that the incidence of the severest forms of smallpox is considerably less among vaccinated than among unvaccinated adult patients (Report, 1968), and haemorrhagic smallpox is much more frequently seen in adults than in children. The severity of the generalized viral infection in haemorrhagic smallpox indicates an unusual lack of resistance on the part of the patient, irrespective of the history of previous vaccinations, but the reason for this susceptibility is unknown. The pregnant woman is five to ten times more prone to develop haemorrhagic smallpox than males or non-pregnant females of the same age group (Rao, Prahlad, Swaminathan \& Lakshmi, 1963), and we have previously suggested that a high level of circulating steroids may be responsible for the severity of smallpox in the pregnant woman.

Sarkar \& Mitra (1967) have suggested that strains of virus isolated from haemorrhagic cases are of enhanced virulence as compared with strains from milder clinical cases of variola major. Epidemiological evidence does not support this view, for contacts of severe cases may suffer from mild clinical illness and haemorrhagic smallpox patients may derive their infection from mild cases. The occurrence of acute fulminating smallpox appears to be dependent on the unusual susceptibility or lack of resistance in the host rather than on enhanced virulence of the infecting strain.

The observations recorded above indicate that in the acute haemorrhagic smallpox case, the culture of smallpox virus from the blood or the demonstration of antigen by the precipitation-in-agar-gel test or the more sensitive CF test may provide confirmation of the diagnosis in the absence of a focal eruption. These examinations may not be so useful in late haemorrhagic cases but in such patients virus or virus antigen can be readily demonstrated in the focal skin lesions. The demonstration of antigen in the blood carries a bad prognosis for we have found it only in patients who succumb to their disease.

\section{SUMMARY}

In practically all acute fulminating smallpox infections-haemorrhagic type I cases - there is severe viraemia with $10^{4}$ or more infective particles of virus per $\mathrm{ml}$. of blood. In most of these patients soluble antigen can be demonstrated in serum by precipitation in agar gel tests, or by the complement-fixation technique. In late haemorrhagic cases (type II) the degree of viraemia is less and soluble antigen is less often demonstrated in the blood. Five of forty type II patients recovered. The majority of the 77 patients studied were adults and bore scars of previous vaccination. Thirteen were pregnant women and 10 of these suffered from type I infections.

The antibody response in patients who survived 6 days or longer as determined by the estimation of precipitins, CF antibodies and neutralizing antibodies in serum, was considerably less than that seen in non-haemorrhagic smallpox patients.

In acute fulminating smallpox infections, the finding of virus or soluble antigen in the blood is of value in establishing the diagnosis. Soluble antigen is usually found 
in the blood of patients suffering from severe viraemia and with the methods used has been demonstrated only in patients who are to die of their disease. Haemorrhagic smallpox represents a generalized virus infection of unusual severity in patients who show little resistance to their infection. The cause of this unusual susceptibility is unknown but there is little evidence that specific allergy to the virus is a feature of this form of the disease.

This investigation was supported in part by Public Health Service Grant AI-1632-16 VR from the National Institute of Allergy and Infectious Diseases, by the World Health Organization and by the Marcus T. Reynolds III Fund.

\section{REFERENCES}

Dixon, C. W. (1962). Smallpox. London: Churchill.

Downie, A W., McCarthy, K., MacDonald, A., MacCallum, F. O. \& Macrae, A. D. (1953). Virus and virus antigen in the blood of smallpox patients. Their significance in early diagnosis and prognosis. Lancet ii, 164-6.

Downie, A. W., St Vincent, L., Goldstein, L., RaO, A. R. \& Kempe, C. H. (1969). Antibody response in non-haemorrhagic smallpox patients. J. Hyg., Camb. 67, 609-18.

Downie, A. W., St Vincent, L., Rao, A. R. \& Kempe, C. H. (1969). Antibody response following smallpox vaccination and revaccination. J. Hyg., Camb. 67, 603-8.

Dumbell, K. R. \& Nizamuddin, M. (1959). An agar-gel precipitation test for the laboratory diagnosis of smallpox. Lancet i, 916-17.

Herrlich, A., Mayr, A. \& Mahnel, H. (1959). Das Antikörperbild der Variola-Vaccineinfektion. 2. Serologische Untersuchungen an Variolapatienten. Zentbl. Bakt. ParasitKde (1 Abt. Orig.) 175, 163-82.

McKay, D. G. \& Margaretten, W. (1967). Disseminated intravascular coagulation in virus disease. Archs intern. Med. 120, 129-52.

McKenzie, P. J., Githens, J. H., Harwood, M. E., Roberts, J. F., Rao, A. R. \& Kempe, C. H. (1965). Haemorrhagic smallpox. 2. Specific bleeding and coagulation studies. Bull. Wld Hlth Org. 33, 773-82.

Mitra, A. C., Chatterjee, S. N., Sarkar, J. K., Manji, P. \& Das, A. K. (1966). Viraemia in haemorrhagic and other forms of smallpox. J. Indian med. Ass. 47, 112-14.

Paniker, C. H. G. \& Kalra, S. L. (1962). Agar gel diffusion precipitation test in the diagnosis of haemorrhagic smallpox. Indian J. med. Res. 50, 686-9.

Ramsay, A. M. \& Emond, R. T. D. (1967). Infectious Diseases. London: Heinemann.

RaO, A. R., Prahlad, I., Swaminathan, M. \& Lakshmi, A. (1963). Pregnancy and smallpox. J. Indian med. Ass. 40, 353-63.

RePort (1968). Smallpox Eradication. Tech. Rep. Ser. Wld Hlth Org. no. 393.

Roberts, J. R., Coffee, G., Creel, S. M., GaAl, A., Githens, J. H., RaO, A. R., Sundara BABU, B. V. \& Kempe, C. H. (1965). Haemorrhagic smallpox. I. Preliminary haematological studies. Bull. Wld Hlth Org. 33, 607-13.

SARKAR, J. K. \& MITRA, A. C. (1967). Virulence of variola virus isolated from smallpox cases of varying severity. Indian J. med. Res. 55, 13-20.

Sarkar, J. K., Chatterjee, S. N. \& Mitra, A. C. (1967). Antibody response in haemorrhagic smallpox. Indian J. med. Res. 55, 1143-9. 